\title{
PENGARUH MODEL PEMBELAJARAN KOOPERATIF TIPE GROUP INVESTIGATION (GI) TERHADAP HASIL BELAJAR FISIKA KOGNITIF TINGGI PADA MATERI POKOK LISTRIK DINAMIS DI MAN 1 MEDAN T.P. 2014/2015
}

\author{
Maylia Bicerdi dan Sahyar \\ Jurusan Fisika FMIPA Universitas Negeri Medan \\ Jalan Willem Iskandar Pasar V Medan, Sumatera Utara \\ mariposaossela@yahoo.co.id
}

\begin{abstract}
ABSTRAK
Penelitian ini bertujuan untuk mengetahui pengaruh model pembelajaran kooperatif tipe grup investigasi terhadap hasil belajar kognitif tinggi siswa pada materi pokok listrik dinamis di kelas X semester II MAN 1 Medan T.P 2014/2015. Jenis penelitian ini adalah penelitian quasi eksperimen dengan kelas eksperimen menggunakan model pembelajaran kooperatif tipe grup investigasi dan kelas kontrol menggunakan pembelajaran langsung. Populasi penelitian seluruh siswa kelas X semester II MAN 1 Medan yang terdiri dari 8 kelas. Sampel penelitian ditentukan dengan teknik claster random sampling. Instrumen yang digunakan adalah tes hasil belajar siswa dalam bentuk pilihan berganda sebanyak 15 soal dengan 5 pilihan jawaban yang telah divalidasi. Berdasarkan hasil pengolahan data post-tes diperoleh bahwa ada pengaruh hasil belajar siswa yang diajar dengan model pembelajaran kooperatif tipe GI terhadap hasil belajar siswa pada materi pokok listrik dinamis di kelas X semester II MAN 1 Medan T.P 2014/2015.
\end{abstract}

Kata Kunci : model pembelajaran kooperatif tipe GI, hasil belajar kognitif tinggi, listrik dinamis.

\begin{abstract}
Study aimed to know the effect of cooperative learning model with group investigation type to ward student's higher order thinking skill in the material dynamic electricity in the class X semester 2 MAN 1 Medan T.P 2014/2015. The type of this research was quasi experimental, with experiment class used cooperative learning model with group investigation type and control class used direct learning. The population was all of the tenth class semester 2 of MAN 1 Medan T.P 2014/2015 which consist of 8 classes. Sample was taken with a cluster random sampling technique. The instrument of the data was the result students learned from the multiple choice in the 15 essay that have been validated. From the data processing post-test showed that there was positive effect of the result students learned by cooperative learning model with GI type from the material dynamic electricity in the class X semester 2 MAN 1 Medan T.P 2014/2015.
\end{abstract}

Keywords : cooperative learning model with group investigation type;higher order thinking skill, dynamic electricity 


\section{PENDAHLUAN}

Pendidikan memiliki peranan yang sangat besar untuk menciptakan masa depan yang gemilang, yang berarti meningkatkan kualitas manusia yang dipersiapkan untuk mengikuti perkembangan Ilmu Pengetahuan dan Teknologi (IPTEK). Kualitas manusia itu sendiri, dominan tergantung kepada kualitas pendidikan yang didapat dari lembaga pendidikan. Menurut Jean Piaget pendidikan sebagai penghubung dua sisi lain nilai sosial, intelektual dan moral yang menjadi tanggung jawab pendidik untuk mendorong individu tersebut. Individu berkembang, perkembangan ini bersifat kausal. Namun terdapat komponen normatif, juga karena pendidikan menuntut nilai. Nilai ini adalah norma yang berfungsi sebagai petunjuk dalam mengidentifikasi apa yang diwajibkan, diperbolehkan dan dilarang. Jadi, pendidikan adalah hubungan normatif antara individu dan nilai.

Pandangan tersebut memberi makna pendidikan adalah segala situasi hidup yang mempengaruhi pertumbuhan individu sebagai pengalaman belajar berlangsung dalam segala lingkungan dan sepanjang hidup. Dalam arti sempit pendidikan adalah pengajaran yang diselenggarakan umumnya di sekolah sebagai lembaga formal. Para ahli psikologi memandang pendidikan adalah pengaruh orang dewasa terhadap anak yang belum dewasa agar mempunyai kemampuan yang sempurna dan kesadaran penuh terhadap hubungan-hubungan dan tugas-tugas sosialnya dalam masyarakat.

Fisika merupakan salah satu cabang Ilmu Pengetahuan Alam (IPA) yang mempelajari tentang gejala-gejala dan fenomena alam. Oleh karena itu, pelajaran fisika seharusnya merupakan salah satu pelajaran yang cukup menarik karena langsung berkaitan dengan kejadian yang nyata yang juga dapat diaplikasikan dalam kehidupan sehari-hari.

Namun pada kenyataanya pelajaran fisika menjadi salah satu mata pelajaran yang memiliki secara umum diperoleh dengan nilai terendah. Alasan mengapa fisika menjadi mata pelajaran yang sulit sangat beragam, salah satunya adalah fisika merupakan pelajaran yang menggunakan terlalu banyak rumus-rumus, yang berupa kalimat matematik sehingga materi ini sulit dipahami oleh sebagian besar siswa. Bahkan tidak sedikit jumlah siswa yang merasa tidak nyaman atau stress ketika akan mengikuti proses pelajaran fisika.

Berdasarkan observasi yang dilakukan di MAN 1 Medan, menunjukkan bahwa hasil belajar siswa yakni nilai yang dicapai pada umumnya belum mencapai nilai Kriteria Ketuntasan Minimal (KKM). Berdasarkan wawancara kepada guru bidang studi Fisika bahwa hasil ulangan harian fisika cukup memuaskan, dimana nilai rata-rata siswa hanya berkisar antara 50-60. sedangkan KKM untuk pelajaran Fisika adalah 70 hanya $5-10$ orang saja yang mampu mencapai nilai tersebut . Nilai yang dicapai siswa ini hanya dapat dikategorikan cukup, karena nilai tersebut tidak hanya diperoleh siswa dari hasil kemampuan belajarnya sendiri melainkan sudah ada penilaian tambahan dari guru, seperti penilaian guru terhadap tugas pribadi, kehadiran siswa, disiplin siswa, dan juga keaktifan siswa pada saat proses pembelajaran berlangsung.

Berdasarkan hasil wawancara peneliti dengan salah seorang guru fisika di MAN 1 Medan, rendahnya hasil belajar siswa tersebut dikarenakan kurangnya pemahaman siswa mengenai konsep-konsep fisika, serta kurangnya aktivitas maupun kerja sama di antara siswa dalam mempelajari fisika. Hal ini dapat terjadi juga karena proses pembelajaran yang sering digunakan yang masih didominasi oleh guru. Tentunya hal ini berimbas pada menurunnya minat belajar terhadap pelajaran fisika itu sendiri.

Strategi yang paling sering digunakan untuk mengaktifkan siswa adalah dengan melibatkan siswa dalam diskusi dalam seluruh kelas. Tetapi strategi ini tidak terlalu efektif, walaupun guru sudah berusaha dan mendorong siswa untuk berpartisipasi. Kebanyakan siswa terpaku 
menjadi penonton sementara arena kelas dikuasai oleh hanya segelintir orang. Suasana kelas perlu direncanakan dan dibangun sedemikian rupa, sehingga siswa mendapatkan kesempatan untuk berintekrasi satu sama lain. Dalam interaksi ini. Siswa akan membentuk komunitas yang memungkinkan mereka untuk mencintai proses belajar dan mencintai satu sama lain. Dalam suasana belajar yang penuh dengan persaingan dan pengisolasian siswa, sikap dan hubungan yang negatif akan terbentuk dan mematikan semangat siswa. Suasana seperti ini akan menghambat pembentukan pengetahuan secara aktif. Oleh karena itu, guru perlu menciptakan suasana belajar yang sedemikian rupa, sehingga siswa bekerja sama secara gotong royong.

Berdasarkan pemaparan masalahmasalah tersebut di atas, salah satu usaha yang dapat dilakukan untuk mengatasinya adalah dengan pemilihan model pembelajaran yang tepat yaitu model pembelajaran yang dapat memperbaiki pemahaman siswa akan konsep-konsep fisika dengan melibatkan siswa secara aktif sehingga siswa dapat belajar secara personal maupun kelompok dengan suasana yang menyenangkan. Dengan demikian, salah satu model pembelajaran yang dapat dipilih adalah model pembelajaran kooperatif. Model pembelajaran kooperatif merupakan suatu model pembelajaran dengan pendekatan pembelajaran yang tepat untuk meningkatkan pemahaman akan konsep-konsep fisika dan juga meningkatkan aktivitas siswa selama proses belajar mengajar berlangsung.

Model pembelajaran kooperatif terdiri dari beberapa jenis, salah satunya model pembelajaran kooperatif tipe group investigation. Model pembelajaran kooperatif tipe group investigation adalah sebuah model yang tidak mengharuskan siswa menghafal fakta, rumus-rumus tetapi sebuah model yang membimbing para siswa mengidentifikasi topik, merencanakan investigasi di dalam kelompok, melaksanakan penyelidikan, melaporkan dan mempresentasikan hasil penyelidikannya. Dalam model pembelajaran ini siswa terlibat secara aktif dalam kegiatan pembelajaran sehingga dengan sendirinya pemahaman akan konsep-konsep fisika tercapai. Di samping itu, siswa dituntut untuk belajar bekerja sama dengan anggota lain dalam satu kelompok. Siswa memiliki dua tanggung jawab yaitu, mereka belajar untuk dirinya sendiri dan membantu sesama anggota kelompok. Pada model pembelajaran ini, seorang siswa berintraksi dengan siswa lain dalam kelompok tanpa memandang latar belakang. Model pembelajaran kooperatif tipe group investigation ini, juga melatih siswa untuk memiliki kemampuan yang baik dalam berkomunikasi dan mengemukakan pendapatnya.

Adapun tujuan yang diperoleh dari penelitian ini adalah: (1) Untuk mengetahui hasil belajar siswa dengan menggunakan model pembelajaran kooperatif tipe group investigation, (2) Untuk mengetahui hasil belajar siswa dengan menggunakan pembelajaran langsung

, (3) Untuk menganalisis apakah hasil belajar siswa yang diajar dengan model Pembelajaran Kooperatif Tipe Group Investigation lebih tinggi dari pada siswa yang diajarkan dengan pembelajaran Langsung.

\section{METODE PENELITIAN}

Penelitian ini dilaksanakan di MAN 1 Medan yang beralamat di Jl. Williem Iskandar, dan pelaksanaannya pada Semester II T.A. 2014/2015. Populasi dalam penelitian ini adalah semua siswasiswi kelas X SMA pada semester genap T.P. 2014/2015, berjumlah 300 siswa yang terbagi dalam 8 kelas. Dengan menggunakan cluster random sampling, sampel diambil dari populasi sebanyak yaitu 2 kelas. Satu kelas dijadikan sebagai kelas eksperimen yaitu menggunakan model pembelajaran kooperatif tipe group investigation dan satu kelas lagi dijadikan sebagai kelas kontrol yaitu menggunakan pembelajaran langsung. 
Variabel bebas dalam penelitian ini adalah model pembelajaran kooperatif tipe group investigation dengan model pembelajaran langsung. Variabel terikat dalam penelitian ini adalah hasil belajar siswa kognitif tinggi pada materi pokok listrik dinamis.

Jenis penelitian ini termasuk quasi experiment. Desain yang digunakan pretest-posttest control group design, seperti ditunjukkan pada Tabel 1.

Tabel 1. Pretest-Posttest Control Group Design

\begin{tabular}{|l|l|l|l|}
\hline $\begin{array}{l}\text { Kelompok/ } \\
\text { Kelas }\end{array}$ & $\begin{array}{l}\text { Pre- } \\
\text { tes }\end{array}$ & $\begin{array}{l}\text { Perla- } \\
\text { kuan }\end{array}$ & Pos-tes \\
\hline Eksperimen & $\mathrm{Y}_{1}$ & $\mathrm{X}_{1}$ & $\mathrm{Y}_{2}$ \\
\hline Kontrol & $\mathrm{Y}_{1}$ & $\mathrm{X}_{2}$ & $\mathrm{Y}_{2}$ \\
\hline
\end{tabular}

Dimana :

$\mathrm{Y}_{1} \quad=$ Tes awal (Pre-tes)

$\mathrm{Y}_{2}=$ Tes akhir (Pos-tes)

$\mathrm{X}_{1} \quad=$ Pembelajaran dengan model pembelajaran kooperatif tipe group investigation

$\mathrm{X}_{2} \quad=$ Pembelajaran langsung

Instrumen yang dilakukan dalam penelitian ini adalah tes hasil belajar siswa berjumlah 30 soal sebelum divalidasi. Setelah divalidasi menjadi 20 soal dalam bentuk pilihan berganda dengan 5 option dan diberikan sebanyak dua kali yaitu pretest dan posttest.

Adapun tahapan-tahapan teknik pelaksanaan penelitian ini adalah sebagai berikut :

\section{Tahap Awal (Persiapan dan Perencanaan)}

Kegiatan yang dilakukan meliputi:

a. Membuat surat persetujuan dosen pembimbing.

b. Menentukan masalah, judul, lokasi, dan waktu penelitian.

c. Menentukan populasi dan sampel d. Melakukan studi pendahuluan (wawancara dengan guru fisika tentang masalah-masalah yang dihadapi siswa dalam pembelajaran fisika, dan melakukan observasi langsung ke sekolah pada saat pelaksanaan pembelajaran).

e. Menyusun dan mengembangkan perangkat pembelajaran serta instrumen penelitian.

\section{Tahap Pelaksanaan Penelitian}

Kegiatan yang dilakukan meliputi:

a. Memvalidkan tes/ instrumen penelitian

b. Menentukan kelas sampel dan kelas kontrol dari populasi yang ada.

c. Melaksanakan pretes pada kelas eksperimen dan kelas kontrol untuk mengetahui kemampuan awal yang dimiliki oleh siswa.

d. Melakukan uji normalitas dan homogenitas data tes awal.

e. Membagi kelompok belajar siswa untuk siswa kelas eksperimen.

f. Melaksanakan pembelajaran dengan model pembelajaran sesuai desain penelitian.

g. Melakukan observasi terhadap kinerja siswa selama pembelajaran berlangsung yakni ketika siswa bekerja berkelompok.

h. Memberikan postes kepada kelas eksperimen dan kelas kontrol untuk mengetahui kemampuan akhir (hasil belajar dan kemampuan berfikir kritis) siswa setelah diberikan perlakuan.

\section{Tahap Akhir Penelitian}

Analisis data dan kesimpulan

Uji validitas yang digunakan pada penelitian ini adalah validitas isi, yaitu item-tem soal divalidkan oleh tim ahli sebagai validator.

Uji normalitas diadakan untuk mengatahui normal tidaknya populasi penelitian tiap variabel penelitian dengan menggunakan uji Lilliefors, dan untuk uji homogenitas data populasi digunakan uji kesamaan varians. 
Pengujian hipotesis dilakukan dengan dua cara yaitu : uji kesamaan rata-rata Pretest (Uji t dua pihak). Uji t dua pihak digunakan untuk mengetahui kemampuan awal siswa pada kedua kelompok sampel. Hipotesis yang di uji berbentuk :

\section{Ho :}

$\mathrm{H}_{\mathrm{a}}$ :

Keterangan :

: kelas eksperimen dan kelas kontrol mempunyai kemampuan awal yang sama

: kelas eksperimen dan kelas kontrol mempunyai kemampuan awal yang berbeda

Untuk mengetahui pengaruh dari suatu perlakuan yaitu Model Pembelajaran kooperatif tipe group Investigation terhadap hasil belajar siswa digunakan Uji t satu pihak. Hipotesis yang diuji berbentuk:

$$
\begin{aligned}
& \mathrm{H}_{0} \\
& \mathrm{H}_{\mathrm{a}} \text { : }
\end{aligned}
$$

Keterangan :

: hasil belajar Fisika dengan model pembelajaran kooperatif tipe group Investigation tidak lebih baik daripada pembelajaran langsung.

: hasil belajar Fisika dengan model pembelajaran kooperatif tipe group Investigation lebih baik daripada pembelajaran langsung.

Kriteria pengujian yang berlaku

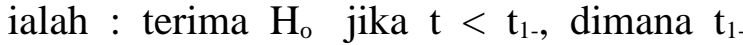
didapat dari daftar distribusi $t$ dengąad $\mathrm{K}_{\mathrm{K}} \overline{\mathrm{e}}$ as $\left(\mathrm{n}_{1}+\mathrm{n}_{2}-2\right)$ dan peluang $\left(\mathrm{t}_{1-}\right)$ dan $=0,05$. jika $\mathrm{t}$ mempunyai harga-harga lain $\mathrm{H}_{0}$ di Pretes tok, yang berarti model Group InvesPretateopntro dikatakan memiliki pengaruh terhadap hasil belajar siswa, yaitu hasil belajar dengan model Group Investigation lebih baik daripada model pembelajaran Langsung.

Jika analisis data menunjukkan bahwa, atau nilai t hitung yang diperoleh lebih dari , maka hipotesis $\mathrm{H}_{\mathrm{o}}$ ditolak dan $\mathrm{H}_{\mathrm{a}}$ diterima. Dapat diambil kesipnquedak hasil belajar siswa pada kelas eksperien lebih besar daripada hasil belajar siswa kelas kontrol, maka model Group Investigation berpengaruh terhadap hasil belajar siswa

\section{HASIL PENELITIAN \\ DAN PEMBAHASAN}

\section{Penelitian}

Tabel-tabel dibawah ini menjelaskan seluruh hasil penelitian yang diperoleh melalui analisis data

Tabel 2. Hasil Pretes Kelas Eksperimen

\begin{tabular}{|c|c|c|c|c|c|}
\hline \multicolumn{4}{|c|}{ Pre-tes kelas eksperimen } & \multicolumn{2}{|r|}{$\operatorname{Pr}$} \\
\hline No & Nilai & $f$ & \multirow{8}{*}{$\begin{array}{l}=47,97 \\
S=10,66\end{array}$} & No & Nila \\
\hline 1 & 20 & 1 & & 1 & 27 \\
\hline 2 & 33 & 4 & & 2 & 40 \\
\hline 3 & 40 & 7 & & 3 & 47 \\
\hline 4 & 47 & 3 & & 4 & 53 \\
\hline 5 & 53 & 11 & & 5 & 60 \\
\hline 6 & 60 & 6 & & & \\
\hline 7 & 67 & 1 & & & \\
\hline & lah & 33 & & & Jumlah \\
\hline
\end{tabular}
dan Kelas Kontrol

Tabel 3. Ringkasan Hasil Perhitungan Nilai Rata-rata, Standar Deviasi dan Varians

\begin{tabular}{|c|c|c|r|}
\hline \multirow{2}{*}{ Keterangan } & \multicolumn{2}{|c|}{ Kelas Eksperimen } & \\
\cline { 2 - 4 } & Pretes & Postes & P \\
\hline Rata-rata & 47,97 & 76,81 & \\
\hline Standar Deviasi & 10,66 & 7,45 & 9 \\
\hline Varians & 113,6 & 55,5 & \\
\hline
\end{tabular}

Tabel 4. Ringkasan Uji Normalitas Data Pretes

\begin{tabular}{l|l|l|l}
\hline & $\mathbf{L}_{\text {hitung }}$ & $\mathbf{L}_{\text {tabel }}$ & Kesimpulan \\
\hline sperimen & 0,137 & \multirow{2}{*}{0,154} & Berdistribusi Normal \\
& 0,045 & & Berdistribusi Normal \\
\hline
\end{tabular}

Tabel 5. Ringkasan Hasil Uji Homogenitas Data Pretes

\begin{tabular}{l|l|l|l|l}
\hline & Varians & $\mathbf{F}_{\text {hitung }}$ & $\mathbf{F}_{\text {tabel }}$ & Kesimpul \\
\hline serimen & 113,6 & \multirow{2}{*}{1,145} & 1,808 & \multirow{2}{*}{ Homogen } \\
\hline ntrol & 99,2 & & &
\end{tabular}

Tabel 6. Ringkasan Perhitungan Uji Hipotesis Pretes Siswa

\begin{tabular}{c|c|l|l|l}
\hline & Nilai Rata rata & $\mathbf{t}_{\text {hitung }}$ & $\mathbf{t}_{\text {tabel }}$ & Kesimpulan \\
\hline & 47,97 & 1,1814 & 1,9987 & $\begin{array}{l}\text { Kemampuan } \\
\text { Sama }\end{array}$ \\
\hline
\end{tabular}


Tabel 7. Hasil Postes Kelas Eksperimen dan Kelas Kontrol

\begin{tabular}{|c|c|c|c|c|}
\hline \multicolumn{4}{|c|}{ Pos-tes kelas eksperimen } & \\
\hline No & Nilai & $f$ & \multirow{7}{*}{$=67,5$} & No \\
\hline 1 & 67 & 8 & & $\frac{1}{1}$ \\
\hline 2 & 73 & 7 & & 2 \\
\hline 3 & 80 & 12 & & 3 \\
\hline 4 & 87 & 5 & & 4 \\
\hline 5 & 93 & 1 & & 5 \\
\hline \multirow{2}{*}{\multicolumn{2}{|c|}{ Jumlah }} & & & 6 \\
\hline & & 30 & & \\
\hline
\end{tabular}

Tabel 8. Ringkasan Uji Normalitas Data Postes

\begin{tabular}{|c|c|c|c|c|}
\hline No & Data Kelas & $\mathbf{L}_{\text {hitung }}$ & $\mathbf{L}_{\text {tabel }}$ & $\overline{\text { Kesimpul }}$ \\
\hline & Postes Eksperimen & 0,1250 & \multirow{2}{*}{0,1610} & Berdistrib \\
\hline & Postes Kontrol & 0,1305 & & Berdistrib \\
\hline & \multicolumn{4}{|c|}{$\begin{array}{c}\text { Tabel 9. Ringkasan Hasil Uji Homogenitas } \\
\text { Data Postes }\end{array}$} \\
\hline To & Kelas & Varians & $\mathbf{F}_{\text {hitung }}$ & $\mathbf{F}_{\text {tabel }}$ \\
\hline & Postes Eksperimen & 55,5 & \multirow{2}{*}{1,665} & \multirow{2}{*}{1,808} \\
\hline & Postes Kontrol & 92,37 & & \\
\hline
\end{tabular}

Tabel 10. Hasil Uji Hipotesis Nilai Postes Siswa

\begin{tabular}{l|l|c|c|c|c}
\hline To & Kelas & Rata-rata & $\mathbf{t}_{\text {hitung }}$ & $\mathbf{t}_{\text {tabel }}$ & Kesimpulan \\
\hline & Eksperimen & 73 & 9,022 & 1,999 & Ada perbedaan \\
\hline \multicolumn{5}{c}{ Hasil }
\end{tabular}

pengujian hipotesis dua pihak untuk pretest diperoleh harga $t_{\text {hitung }}<t_{\text {tabel }}$ $1,9212<2,0006$, berarti $\mathrm{H}_{0}$ diterima, sehingga dapat disimpulkan bahwa kemampuan awal siswa pada kelas eksperimen sama dengan kemampuan awal siswa pada sebelum diberikan perlakuan. Dan hasil pengujian hipotesis satu pihak untuk posttest diperoleh harga $t_{\text {hitung }}>t_{\text {tabel }}$ yaitu $3,099>1,668$ maka $\mathrm{H}_{\mathrm{o}}$ ditolak dan $\mathrm{H}_{\mathrm{a}}$ diterima dengan kata lain bahwa ada pengaruh pengaruh penerapan model pembelajaran kooperatif tipe group investigation terhadap hasil belajar siswa pada materi pokok listrik dinamis di kelas $\mathrm{X}$ semester II MAN 1 Medan 2014/2015.

T.P.

\section{Pembahasan}

Data hasil pretes rata-rata kelas eksperimen sebesar 47,97 dan kelas

kontrol 47,51. kedua kelas
ustibormal sampel
diberikan perlakuan yang berbeda. Pada kelas eksperimen diberi perlakuan dengan model pembelajaran kooperatif tipe group investigation dan pada kelas kontrol diberi perlakuan dengan pembelajaran

langsung maka diperoleh rata-rata postes untuk kelas eksperimen sebesar hasirlobelajaflan kelas kontrol 57,39.

\section{dilakukan}

Sebelum

perlakuan, maka nilai pretes pada kedua kelas sampel dianalisis untuk menunjukkan

bahwa data yang diperoleh

berdistribusi secara normal dan kedua sampel berasal dari populasi yang homogen. Hasil analisis menunjukkan

bahwa data yang diperoleh

berdistribusi secara normal dan kedua sampel berasal dari populasi yang homogen.

Dilakukan uji beda pada nilai pretes kedua kelas sampel dengan

menggunakan uji $\mathrm{t}$ dua pihak, hasil analisis dapat dilihat pada tabel 4.7. diperoleh bahwa harga < $\quad(0,1814<$ 1,9987) atau dapat dinyatakan bahwa kemampuan awal siswa pada kelas eksperimen sama dengan kemampuan awal siswa pada kelas kontrol. Hasil penelitian

menunjukkan

bahwa

ada

perbedaan hasil belajar siswa akibat pengaruh model pembelajaran

kooperatif tipe group investigation terhadap hasil belajar siswa pada materi pokok Listrik Dinamis di kelas $\mathrm{X}$ MAN 1 Medan, diperoleh $(9,022>1,999)$.

kelebihan $\begin{array}{r}\text { Adapun } \\ \text { yang }\end{array}$
dapat diberikan
dengan
menggunakan
model pembelajaran


kooperatif tipe $G I$ adalah model pembelajaran ini merupakan model pembelajaran yang melibatkan seluruh siswa dalam belajar terlihat dari hasil observasi siswa termaksud dalam kategori aktif. Model ini adalah cara yang efektif dalam mencapai hasil belajar akademik maupun sosial dan secara khusus bermakna dalam keadaan untuk menekankan pentingnya belajar kolektif, siswa dapat menukar ide satu sama lain, mendorong dan mengembangkan

kerja sama antar siswa,

meningkatkan

keterampilan

berkomunikasi

siswa,

meningkatkan

pemahaman siswa secara mendalam terhadap materi melalui eksplorasi, meningkatkan

percaya diri siswa dan meningkatkan penerimaan mereka terhadap perbedaan individual.

Dalam

model pembelajaran kooperatif tipe GI, siswa menjadi subjek (pelaku) belajar sedangkan yang menjadi objek adalah materi atau bahan yang sedang dipelajari. Berbeda dengan pembelajaran langsung dimana guru sebagai subjek yang begitu aktif menyampaikan materi pelajaran dan siswa merupakan objek pasif yang harus mendengarkan guru sehingga kegiatan belajar mengajar cenderung membosankan bagi siswa.

\begin{tabular}{lrlr}
\multicolumn{1}{c}{ Hasil } & Dwi & Wahyuni, \\
penelitian & ini & Fihrin & dan \\
sejalan & dengan & Muslimin &
\end{tabular}
penelitian terdahulu menyatakan bahwa seperti yang di teliti model pembelajaran oleh Suheni (2013), kooperatif tipe menyatakan dalam group investigation hasil penelitiannya terjadi peningkatan rata-rata hasil belajar kognitif siswa yang diajar dengan model pembelajaran kooperatif tipe group investigation. Ade Mayasari, Akmam, Nurhayati (2013), menyatakan adanya perbedaan hasil belajar IPA Fisika siswa antara kelas eksperimen dengan kelas kontrol pada ranah kognitif.

S.Widowati, H.Susanto, A.Yulianto (2013), menyatakan adanya peningkatan hasil belajar kognitif siswa kelas

eksperimen yang lebih tinggi dibandingkan kelas kontrol. Praptiwi dan Jeffry Handhika menyatakan Ada perbedaan

penggunaan metode pembelajaran

kooperatif tipe GI (Group

Investigation) dan STAD (Student

Teams Achievement Divisions) terhadap prestasi belajar fisika. efektif

meningkatkan hasil belajar fisika pada siswa. dan I Gede Ramaya menyatakan bahwa implementasi model pembelajaran tipe GI dpat meningkatkan hasil belajar.

Di samping kelebihan yang diberikan, dalam penelitian yang dilaksanakan juga memiliki beberapa kelemahan antara lain, pada waktu pembentukan

kelompok asal dan bergabungnya kelompok ahli dalam satu tempat, keadaan kelas menjadi ricuh ketika siswa berpindah tempat mencari teman sekelompoknya.

Selain itu,adanya keterbatasan jumlah alat yang membuat siswa secara keseluruhan tidak dapat menyaksikan langsung dan cara penggunaanya, serta siswa juga kurang memahami materi sebelumnya yang sangat berhubungan dengan materi yang diberikan oleh peneliti dan siswa kurang percaya diri dengan kemampuan yang dimilikinya sehingga siswa cenderung bertanya kepada peneliti. Hal ini disebabkan karena siswa sudah terbiasa dengan pembelajaran

langsung, dimana guru merupakan sumber utama dari pengetahuan yang didapat siswa.

\section{Karena}

siswa bekerja secara kelompok dari tahap perencanaan sampai investigasi untuk menemukan hasil jadi metode ini sangat komplek, sehingga guru harus mendampingi siswa secara penuh agar mendapatkan hasil yang diinginkan. 


\section{KESIMPULAN}

Berdasarkan

hasil analisis dan uji

statistik serta

pembahasan maka

disimpulkam Nilai

rata-rata hasil

belajar siswa

kognitif tinggi

dengan

menggunakan

Model

Pembelajaran

Kooperatif Tipe

Group Investigation

sebesar 76,81. Nilai

rata-rata hasil

belajar siswa

kognitif tinggi

dengan

menggunakan

Model

Pembelajaran

Langsung sebesar 57,39 .

Dari hasil uji

hipotesis $t_{\text {hitung }}=$

$9,022>t_{\text {tabel }}=1,999$

sehingga hasil

belajar siswa

dengan menerapkan

Model

Pembelajaran

Kooperatif Tipe

Group Investigation memiliki pengaruh yang lebih tinggi dibandingkan

dengan Model

Pembelajaran

Langsung.

DAFTAR

PUSTAKA

Arikunto,

S.,

(2006),

Prosedur

Penelitian

Suatu

Pendekatan
Praktek, PT.

Rineka Cipta,

Jakarta.

Istarani, (2012), 58

Model

Pembelajara

$n$

Pembelajara

$n \quad$ Inovatif,

Media

Persada,

Medan.

Mayasari,

A.,

Akmam, dan

Nurhayati,

(2013),

Pengaruh

Penerapan

Model

Pembelajaran

Kooperatif

Tipe Group

Investigation

Berbantukan

Lks Terhadap

Hasil Belajar

Ipa Fisika

Siswa Kelas

VII SMP N 8

Padang, Pillar

Of Physics

Education,

Vol. 2.

Praftiwi,

i, dan

Handika, J.,

(2012),

Efektivitas

Metode

Kooperatif

Tipe GI dan

STAD

Ditinjau dari

Kemampuan

Awal, Jurnal

Penelitian

Pembelajaran

Fisika Vol. 3

No. 1 .

Ratnaya, I Gede,

(2012),
Implementasi

Pembelajaran

Kooperatif

Tipe Group

Investigation

Untuk

Meningkatkan

Aktivitas dan

Hasil Belajar

Matematika,

Jurnal

Pendidikan

dan

Pengajaran,

Jilid 46,

Nomor 2, Juli

2013,

hlm.125-135.

Slavin, E. Robert., (2010),

Cooperative

Learning,

Nusa Media:

Bandung

Sudjana, (2005),

Metode

Statistika,

Tarsito,

Bandung.

Sudjana, N, (2009),

Penilaian

Hasil Proses

Belajar

Mengajar,

Bandung,

Remaja

Rosdakarya.

Trianto, (2009),

Mendesain

Model

Pembelajaran

Inovatif

Progresif

Konsep,

Landasan,

dan

Implementasin ya pada

KTSP,

Kencana

Prenanda

Media Group,

Jakarta.

Wahyuni, D.,

Fihrin, dan

Muslimin,

(2014),

Efektivitas

Model

Pembelajaran

Kooperatif

Tipe Group

Investigation

Terhadap

Hasil Belajar

Fisika pada

Siswa Kelas

XI MA

Alkhairaat

Kalangkangan

, Jurnal

Pendidikan

Fisika

Tadulako

(JPFT) Vol. 2

No. 1.

Widowati, S.,

Susanto, H., dan Yulianto,

A., (2013),

Pengaruh

Pembelajaran

Kooperatif

Tipe Group

Investigation

Berbasis

Eksperimen

Inkuiri

Terhadap

Motivasi

Belajar

Siswa, Upej

2 (2). 